UDC 336.1:338.24

JEL: H50; H56

\section{THE ROLE OF SUPPORT AND FINANCING OF THE ARMED FORCES AS ONE OF THE KEY ELEMENTS OF THE STABILITY OF THE UKRAINIAN ECONOMY AND ENSURING ITS SUSTAINABLE GROWTH}

Introduction. Military conflicts cause a lot of destructive influences not only on the political situation in the country but of course on its the financial system. That's why in this article, the main emphasis of the research was done on risk-ratio analysis of the Ukraine and Israel economies since the role of military budget expenditures in the whole financial system is growing. Military finance is one of the biggest components of the financial system of Ukraine. So, according to the nowadays situation and military conflict in Ukraine appears the necessity of searching for new ways to increase this kind of expenditures efficiently.

Aim and tasks. The problem of the research was to measure risks of the economies according to the GDP trends and to find the place of the military expenditures in all government expenditures.

Results. In the research results, it should be mentioned that the most difficult approach for comparing is the international currency, which is weighed against the depreciation of cash flows in time. However, the research used the current exchange rate for convenience. But, this does not have a significant effect on the interpretation of the results of the research, presented in the form of a CAPM analysis of the economies of countries and their defense expenditures. After all, trends are generally observed over a period of time that has been analyzed. The general state of financial systems in the regions was analyzed as the value of volatility, aggregate risks and the overall growth of the economy. The US GDP, as for an example of the largest economy in the world, served as a comparative basis. It correlates and affects all other financial markets. The obtained results made it possible to draw conclusions about the attractiveness of the state for potential investors, despite armed conflicts with neighbors in the territory and areas of influence on the regions under control. In this paper, a standard statistical analysis package was used using an example of linear regression with one variable. The power of the influence of military expenditures was measured by the ratio of variables and their correlations. The obtained results were characterized by a high level of interconnection power and reliability of the hypotheses obtained. This gives an opportunity to describe the role of military conflicts and support the Armed Forces for the state economy.

Conclusions. The result of the presented research of the role of support and financing of the Armed Forces as one of the key elements of the stability of the Ukrainian economy and ensuring its sustainable growth is the sustaining of the military expenditures for Ukraine. The presented conclusion was approved on the Israel example and calculations. This approach and methodology is universal and can be used for other researches.

Keywords: military expenditure, military budget, financial support, risk-ratio analyses, Armed Forces, GDP.
(C) Economics. Ecology. Socium, 2019

CC BY-NC 4.0 license 
УДК 336.1:338.24

JEL: H50; H56

\section{Вадим Пахольчук}

ад'юнкт,

Військовий інститут Київського національного університету імені Тараса Шевченка, м. Київ, Україна E-mail: vadym.pakholchuk@gmail.com orcid.org/0000-0002-9657-6148

Отримано: Січень, 2018

Прийнято: Лютий, 2019

DOI:10.31520/2616-7107/2019.3.1-3

(C) Економіка. Екологія. Соціум, 2019 CC BY-NC 4.0 ліцензія

\section{РОЛЬ ПІДТРИМКИ ТА ФІНАНСУВАННЯ ЗБРОЙНИХ СИЛ ЯК ОДИН ІЗ КЛЮЧОВИХ ЕЛЕМЕНТІВ СТАБІЛЬНОСТІ ЕКОНОМІКИ УКРАЇНИ ТА ЗАБЕЗПЕЧЕННЯ П̈І СТАЛОГО ЗРОСТАННЯ}

Вступ. Збройні конфлікти викликають багато руйнівних впливів не тільки на політичну ситуацію в країні, але й на іiі фінансову систему. Тому в цій статті основна увага приділена дослідженню аналізу співвідношення ризиків економіки України та Ізраїлю, оскільки роль видатків військового бюджету для всій фінансовій системі зростає. Військові фінанси є однією з найбільших складових фінансової системи України. Отже, відповідно до нинішньої ситуації та військового конфлікту в Україні виникає необхідність у пошуках нових шляхів для ефективного збільшення цих видів витрат.

Мета і завдання. Мета дослідження полягала в тому, щоб оцінити та виміряти ризики економік відповідно до тенденцій ВВП і знайти місце військових витрат у всіх державних витратах.

Результати. У результатах дослідження потрібно зауважити, що найскладнішим підходом для порівняння $€$ міжнародна валюта, зважена на знецінення грошових потоків у часі. Однак у дослідженнях використано поточний обмінний курс валюти для зручності. Проте це не має значного впливу на інтерпретацію результатів дослідження, представлених у вигляді САРМ аналізу економік країн та їх видатків на оборону. Адже в цілому прослідковуються тренди за проміжок часу, що був проаналізований. Загальний стан фінансових систем у регіонах був проаналізований, як значення волатильності, сукупних ризиків та росту економіки в цілому. Порівняльним базисом слугувало ВВП США, як найбільша економіка у світі. Вона корелює та впливає на всі інші фінансові ринки. Отримані результати дали змогу зробити висновки про привабливість держави для потенційних інвесторів, незважаючи на збройні конфлікти з сусідами за території та сфери впливу в межах підконтрольних регіонів.

У роботі використовувався стандартний пакет статистичного аналізу на прикладі лінійної регресії 3 однією змінною. Потужність впливу військових витрат вимірювалася співвідношенням змінних та їх кореляціями. Отримані результати характеризувалися високим рівнем сили взаємозв'язків та надійності отриманих гіпотез. Це дає можливість описати роль військових конфліктів та підтримки Збройних Сил для економіки держави.

Висновки. Результатом проведеного дослідження ролі підтримки та фінансування Збройних Сил як одного 3 ключових елементів стабільності української економіки та забезпечення іiі стійкого зростання $\epsilon$ обгрунтування необхідності підтримки військових витрат для України. Представлений висновок доведений на прикладі Ізраїлю та математичних розрахунках. Цей підхід i методологія $\epsilon$ універсальними i можуть бути використані для інших досліджень.

Ключові слова: військові витрати, військовий бюджет, фінансова підтримка, ризик аналіз, Збройні Сили, ВВП. 
Introduction. The country's financial system is complex and complicated. The interrelation of its components can be explained only by analyzing various components and their mutual influence. However, given the development of the world financial system and the importance of a systematic, integrated approach to the economy, it becomes impossible to ignore the correlation of the Ukrainian system with global markets. At the same time, public finances play an important role in sustainable growth. The finances of the Armed Forces are an important component in their structure. Specific economic ties that have an impact on various spheres of the state's economy characterize them. The sequence of economic analysis and its completeness will characterize the complexity of the general approach to evaluating the economic growth of the state, the place, and role of the Armed Forces finances. Today, the priority is to ensure sustainable development and growth of gross domestic product at the level of $3-4 \%$ per year. The faster pace can be achieved due to favorable investment policy and stability, in our case, mainly in the military-political field. That is why the financing of the development and reform of the Armed Forces, the effective spending of the allocated financial resources, is one of the important factors for stabilizing the situation in the region, which may create the necessary basis for the growth of the economy. In this context, it is indispensable to focus on the study of the risks of the domestic system in comparison with similar foreign analogs in accordance with the basic indicators, as well as the power of influence of the Armed Forces finances.

Analysis recent research and publications. The problems of financial security of the Armed Forces were studied by a large number of domestic scientists, among them M. Semenikhin, Ju. Medvedjev, I. Vashhenko, B. Andresjuk, C.Vikulov, V. Tkachev, V. Ushakov, V. Fedosov, O. Cheberyako, Z. Varnalij and others [1-6]. However, taking into account the current state of globalization processes and the development of a market economy, a complex militarypolitical situation, in their studies they did not pay enough attention to the impact of troop financing on ensuring sustainable development of the state's economy. Recently, the emphasis was done on research on the prerequisites of the war, the disclosure of the essence of the "hybrid war", its economic effect. Therefore, the study focuses on articles by foreign authors and their views on defense spending, GDP and the development of the economy of H. Çakmak, A. Razin, A. Avigur-Eshel, D. Filc, B. Phillips, P. Yesilyurt, E.Esilurta, T. Sandler [7, 17, 18, 21-23], and others. The theme of the work remains relevant in connection with the participation of Ukraine in armed conflicts and the build-up of its defense potential, which, in the conditions of a market economy and limited financial resources, necessitates the justification of defense expenditures.

Aim and tasks. The aim of the study is to carry out a risk analysis of the economies of Israel and Ukraine as a state that participates in military conflicts. The proxy base will serve the US GDP as the main driving force behind global economic growth, which correlates with all other financial markets. At the same time, the force of influence and attachment of expenditures on ensuring the state's defense capability to the sustainability of economic growth will be analyzed.

Results. The attention of scientists has always caused the study of the development of economies of new countries, which have only recently appeared on the political map of the world. Moreover, the processes of state building somewhat stabilized in the XXI century. However, there are a lot still quite young states, the emergence of which is of particular interest due to the complex development process, as well as the military-political situation with its neighbors. Armed conflicts have become more complex and complicated in our time than in previous years due to the strengthening of ethnic, nationalist movements and energy crises that were caused by a section of resources, including water, oil, or other energy sources. In response to these events, military spending is rising all over the world. For global purposes and establishing control status in the regions, challenging real or potential conflicts and increasing the availability of economic resources, they play an important role for analysts [7]. The question of our study is also to test the hypothesis of the impact of these costs on ensuring sustainable economic growth. 
The MSCI ACWI Index Market Allocation is one of the best and most effective indexes that allows you to analyze the state of the country's economic development and its risks. In our study, Israel's economy will serve as a comparative base. However, as indicated in the index of MSCI ACWI Index Market Allocation, Israel is already in the category of developed investment markets, while Ukraine has emerged from the emerging market category and is potentially not interesting to investors. The MSCI Emerging Markets Index or the MSCI Frontier Markets Index are not included in the MSCI Standalone Market Indices. However, the MSCI Standalone Markets uses the same methodology and criteria for determining the size of markets and their liquidity [8].

\begin{tabular}{|c|c|c|c|c|c|c|c|c|c|c|}
\hline \multicolumn{11}{|c|}{ MSCI ACWI \& FRONTIER MARKETS INDEX } \\
\hline \multicolumn{6}{|c|}{ MSCI ACWI INDEX } & \multicolumn{5}{|c|}{ MSCI EMERGING \& FRONTIER MARKETS INDEX } \\
\hline \multicolumn{3}{|c|}{ MSCI WORLD INDEX } & \multicolumn{3}{|c|}{ MSCI EMERGING MARKETS INDEX } & \multicolumn{5}{|c|}{ MSCI FRONTIER MARKETS INDEX } \\
\hline \multicolumn{3}{|c|}{ DEVELOPED MARKETS } & \multicolumn{3}{|c|}{ EMERGING MARKETS } & \multicolumn{5}{|c|}{ FRONTIER MARKETS } \\
\hline Americas & $\begin{array}{l}\text { Europe \& } \\
\text { Middle East }\end{array}$ & Pacific & Americas & $\begin{array}{l}\text { Europe, Middle } \\
\text { East \& Africa }\end{array}$ & Asia & Americas & $\begin{array}{l}\text { Europe \& } \\
\text { CIS }\end{array}$ & Atrica & Middle East & Asin \\
\hline \multirow[t]{3}{*}{$\begin{array}{l}\text { Canada } \\
\text { United States }\end{array}$} & $\begin{array}{l}\text { Austria } \\
\text { Belgium } \\
\text { Denmark } \\
\text { Finland } \\
\text { France } \\
\text { Germany } \\
\text { Ireland } \\
\text { Israel } \\
\text { Italy } \\
\text { Netherlands } \\
\text { Norway }\end{array}$ & $\begin{array}{l}\text { Australia } \\
\text { Hong Kong } \\
\text { Japan } \\
\text { New Zealand } \\
\text { Singapore }\end{array}$ & $\begin{array}{l}\text { Brazil } \\
\text { Chile } \\
\text { Colombia } \\
\text { Mexico } \\
\text { Peru }\end{array}$ & $\begin{array}{l}\text { Czech Republic } \\
\text { Egypt } \\
\text { Greece } \\
\text { Hungary } \\
\text { Poland } \\
\text { Qatar } \\
\text { Russia } \\
\text { South Africa } \\
\text { Turkey } \\
\text { United Arab } \\
\text { Emirates }\end{array}$ & $\begin{array}{l}\text { China } \\
\text { India } \\
\text { Indonesia } \\
\text { Korea } \\
\text { Malaysia } \\
\text { Pakistan } \\
\text { Philippines } \\
\text { Taiwan } \\
\text { Thailand }\end{array}$ & Argentina & $\begin{array}{l}\text { Croatia } \\
\text { Estonia } \\
\text { Lithuania } \\
\text { Kazakhstan } \\
\text { Romania } \\
\text { Serbia } \\
\text { Slovenia }\end{array}$ & $\begin{array}{l}\text { Kenya } \\
\text { Mauritius } \\
\text { Merocco } \\
\text { Nigeria } \\
\text { Tunisia } \\
\text { WAEMU2 }\end{array}$ & $\begin{array}{l}\text { Bahrain } \\
\text { Jordan } \\
\text { Kuwait } \\
\text { Lebanon } \\
\text { Oman }\end{array}$ & $\begin{array}{l}\text { Bangladesh } \\
\text { Sri Lanka } \\
\text { Vietnam }\end{array}$ \\
\hline & Spain & & \multicolumn{8}{|c|}{ MSCI STANDALONE MARKET INDEXES' } \\
\hline & $\begin{array}{l}\text { Switzerland } \\
\text { United } \\
\text { Kingdom }\end{array}$ & & & Saudi Arabia & & $\begin{array}{l}\text { Jamaica } \\
\text { Panama } \\
\text { Trinidad \& } \\
\text { Tobago }\end{array}$ & $\begin{array}{l}\text { Bosnia } \\
\text { Herzegovina } \\
\text { Bulgaria } \\
\text { Ukraine }\end{array}$ & $\begin{array}{l}\text { Botswana } \\
\text { Ghana } \\
\text { Zimbabwe }\end{array}$ & Palestine & \\
\hline
\end{tabular}

Fig. 1. MSCI ACWI \& Frontier markets index

In the study, were analyzed the interdependence between the US, Israel, and Ukraine economies, the strength of their correlation. The key indicator in the study will be GDP as an element that reflects the development and trends of economic growth at a certain time interval. The methodological basis of the study will be the analysis of risks and coefficients based on the CAPM model [9].

An important issue in the analysis is the verification of data and their analysis, comparability. As noted in studies conducted earlier, use the GDP of states were used not in local currency, but in US dollars [10]. For the convenience of conducting calculations without taking into account inflation and seasonal bindings. The reliability of the data for calculations was provided by comparing the data of the World Bank and the US Federal Reserve [11-14].
OECD examined the effects of GDP weighting and its impact on country weights in a global allocation. GDP weighting assigns a higher weight to emerge markets and lower weight to developed markets and has led to the superior long-run performance of the MSCI ACWI, MSCI World, and MSCI EM GDP Weighted Indices in the past 40 years, compared to their market capitalization counterparts. However, it is not clear that there are fundamental reasons for the outperformance of this strategy or if it will continue to outperform in the future [15]. That is why the research, based upon the GDP is so interesting for us.

Israel's economy continues to register remarkable macroeconomic and fiscal performance. Growth is strong and unemployment low and falling. With low-interest rates and price stability, financial policy is prudent, and public debt is comparatively low and declining. 
The external position is solid, thanks to a dynamic high-tech sector. The average standard of living is improving, mainly due to higher employment rates. Continued accommodative macro policies and planned investments in the offshore gas fields in the coming years will spur further growth. Against this backdrop, Israelis remain on average more satisfied with their lives than residents of most other OECD countries [16].

Sometimes people compare it with a tech cradle of this region and the clue is that Israel, which has the fourth lowest share of direct ICT investment on GFCF (4.2\%), shows the highest shares of total (direct plus indirect) ICT investment $(8.2 \%)$, together with the Czech Republic in OECD [17].

Perhaps the secret of the country's economic success lies in its military conflicts? Ben-Zion Zilberfarb tried to find an answer in his research. Is it possible to conclude that the war has a positive economic impact on the economy? The answer to this question is clearly negative. The effect depends on the initial conditions. In the particular case that was discussed in the study, the Israeli economy entered the war in the midst of the Keynesian recession. Under these circumstances, the expansion of demand caused by the war stimulated the economy and led to economic recovery. However, with another set of initial conditions, the effect of the war may be quite different. Indeed, six years later, in October 1973, the Yom Kippur War broke out. As described earlier, by then the Israeli economy had grown rapidly. The growth in aggregate demand caused by the war, coupled with the negative shock of supply caused by the first oil embargo, had an extremely negative impact on the Israeli economy. This led to a long period of stagflation, which ended only 12 years later [18].

It is important to study the behavior of monetary policy in relation to setting interest rates in five countries. Among them were Indonesia, Israel, South Korea, Thailand, and Turkey. They have adopted inflation targeting in their policies. In addition to the classical linear Taylor rule, it was supplemented with one including the exchange rate has also been considered, It describes the fact that monetary policies in these countries frequently intervene in the foreign exchange markets. This solution is done only when there are large deviations. The total pass from exchange rates to import and consumer prices is well documented. It could force central banks targeting price stability to tighten their monetary policy, in the case of depreciation. This could lead to a loss of international competition in the case of an appreciation [19].

Table 1. Risk analysis of Israel and Ukraine economies

\begin{tabular}{|l|c|c|c|}
\hline \multicolumn{1}{|c|}{ GDP Characteristics } & Units & Israel & Ukraine \\
\hline Mean return & $\mathbf{\%}$ & $7.69 \%$ & $3.79 \%$ \\
\hline Cumulative (accrued) return & $\mathbf{\%}$ & $600.60 \%$ & $50.13 \%$ \\
\hline Correlation & number & 0.20 & 0.20 \\
\hline Standard Deviation $(\sigma)$ & $\mathbf{\%}$ & $7.74 \%$ & $19.51 \%$ \\
\hline Beta stock (systematic risk) 1st formula & times & 0.7944 & 2.0707 \\
\hline Beta stock (systematic risk) 2nd formula & times & 0.7944 & 2.0707 \\
\hline Alpha & $\mathbf{\%}$ & $3.3910 \%$ & $-3.3391 \%$ \\
\hline Expected CAPM, r & $\mathbf{\%}$ & $4.30 \%$ & $7.13 \%$ \\
\hline CV & times & 1.01 & 5.14 \\
\hline $\mathrm{R}^{2}$ 1st formula & times & 0.0393 & 0.0420 \\
\hline $\mathrm{R}^{2}$ 2nd formula & times & 0.0393 & 0.0420 \\
\hline Residual risk (Unsystematic risk) (Sigma e) & $\%$ & $7.58 \%$ & $19.10 \%$ \\
\hline Total Risk (Sigma portfolio) & $\%$ & $27.59 \%$ & $43.88 \%$ \\
\hline
\end{tabular}

Source: Made by the author based on self-calculus.

As can be seen from the analysis of risks, the cumulative (accrued) yield of Israel since 1987 is $600 \%$ compared with $50.13 \%$ of Ukraine. This is a very high rate, but let's take a closer look at risk indicators and average returns. Israel's average income, not surprisingly, considering cumulative (accrued) profits in this period is much higher than in Ukraine, $7.69 \%$ versus $3.79 \%$. A correlation of 0.20 points to a positive weak link between Israel's profitability and Ukraine's GDP to comparable US markets $(\mathrm{Rm})$. The standard deviation $(\sigma)$ of $7.74 \%$ indicates average volatility and comparable stability. 
On the contrary, Ukraine has a high volatility of about $19.51 \%$. This reflects the preconditions for risks. Alpha of Israel also shows that it was chosen to analyze a market that is promising for growth, and an investor could make a long position for him. Ukraine's Alpha is negative and indicates that for potential investors it is a short-term position. If all the necessary conditions and statistics are maintained, then the prospect of the expected CAPM of $4.30 \%$ and $7.13 \%$ should remain unchanged for the same period of the research. Ukraine with a higher risk of losses will lose against the comparable sample. The CV of Israel vs. USA 1.01 and against 5.14 Ukraine, which means low-risk countries (country risk) for Israel, but for Ukraine. In addition, another conclusion for a long position can be made. $\mathrm{R}^{2}$ is very low, so could be asserted that the Israeli-Ukrainian market is not tied to the American market very closely, so it will be a good option for diversification. And despite the fact that
Unsystematic risk (Sigma e) is $7.58 \%$ and is at an average level, Total Risk (Sigma portfolio) is $27.59 \%$. Ukraine has a high risk of about $19.10 \%$ / $43.88 \%$. Significant influence is provided by the beta coefficient (systematic risk) of 0.7944 for Israel and 2.07 for Ukraine, reflecting the overall risks of the Israeli economy in the long run. Thus, based on the risk analysis, the conclusion is that the Israeli economy will be a profitable investment strategy in general, since it has good profitability and stability, risk and almost isolated assets from adverse events in the US markets. However, investments are likely to be better in the direction that will enable you to quickly eliminate positions, taking into account long-term risks. To select specific investment tactics, you need to study specific sectors of the economy of Israel. In this case, the analyst cannot recommend Ukraine as a good investment decision because of high risks and volatility. General trends are described in the graph below.

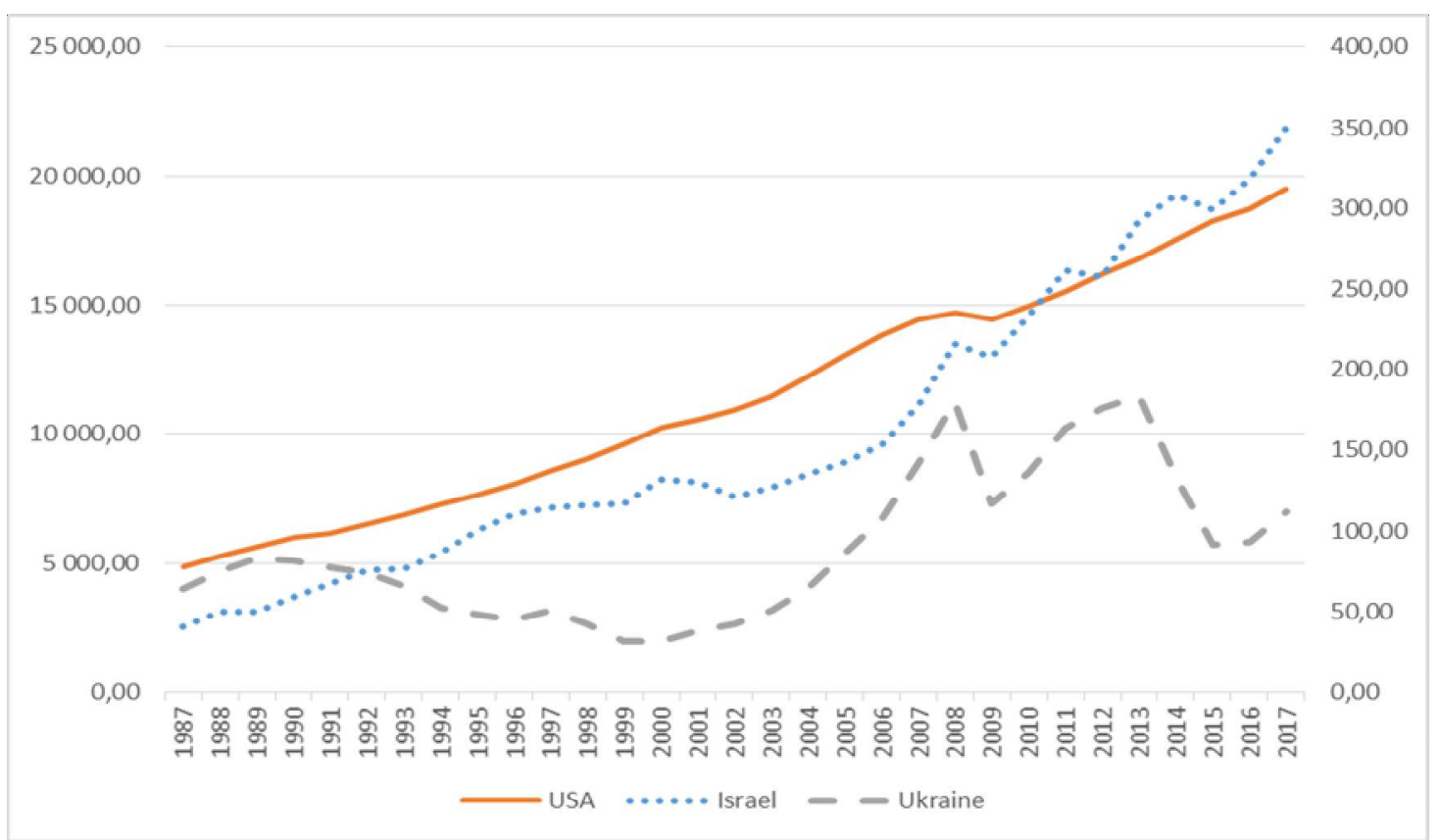

Fig 2. GDP of the USA, Israel, and Ukraine, [billions of dollars] Source: Made by the author based on FRED data

At the same time, the average annual GDP growth rate (CAGR) has been calculated, using the formula below, which allows you to see a real cumulative rate of growth.

$$
C A G R=\left(\frac{\text { End }}{\text { Beginning }}\right)^{\frac{1}{\text { years }}}-1
$$

CAGR shows positive trends for three and five year periods. Although it should be noted that when recalculating in annual percentage changes in GDP growth, negative effects are observed during periods of economic crisis, as expected, as well as in armed conflicts and instability. In the process of analysis, it could be concluded that Israel's economy is showing steady growth, despite the existing militarypolitical challenges in the region. With territorial and resource constraints, Israel is effectively using monetary policy. 
The next step for us is to compare the strength of the relationship of defense spending in Ukraine and Israel.

In this case, SIPRI, WMEAT $[19,20]$ data for the period 1993-2017 was used for assuring the reliability of the analysis. As seen from Table 2, over the past five years, despite the maintenance of a larger army, our spending is four times less than Israel, which is also due to much lower GDP.

Table 2. GDP and Defense expenditures of Ukraine and Israel for the past 5 years, [billions of dollars]

\begin{tabular}{|c|c|c|c|c|}
\hline Date & Israel GDP & Defense expenditures & Ukraine GDP & Defense expenditures \\
\hline 2017 & 350.85 & 16.49 & 112.15 & 3.65 \\
\hline 2016 & 317.75 & 14.78 & 93.27 & 3.42 \\
\hline 2015 & 299.09 & 16.96 & 91.03 & 3.62 \\
\hline 2014 & 308.42 & 18.48 & 133.50 & 4.03 \\
\hline 2013 & 292.49 & 17.30 & 183.31 & 4.39 \\
\hline
\end{tabular}

Source: Made by the author based on Military expenditure by country, in millions of USD at current prices and exchange rates, 1949-2017 (C) SIPRI 2018

Although the growth rate of military expenditures for most countries is usually below the national GDP growth, this ratio is higher than the GDP growth rate in some developing countries, including Israel. However, for substantiated conclusions in their expediency, it is necessary to conduct an econometric analysis of the force of influence of indicators. For this purpose, using the usual single-factor linear regression for the information array, partly shown in the table above for the period from 1993 to 2017 . The results for comparability are presented in the form of Table 3.

Table 3. Regression statistics

\begin{tabular}{|c|r|r|}
\hline Regression statistics & \multicolumn{1}{|c|}{ Israel } & \multicolumn{1}{c|}{ Ukraine } \\
\hline $\mathrm{R}$ & 0.96 & 0.92 \\
\hline $\mathrm{R}^{2}$ & 0.92 & 0.84 \\
\hline Normal R & 0.91 & 0.83 \\
\hline Standard Error & 24.82 & 20.97 \\
\hline Estimations & 25 & 25 \\
\hline
\end{tabular}

Source: Made by the author based on self-calculus

Regression statistics confirm the existence of a stable relationship between defense spending and GDP of Ukraine and Israel. It should be noted that it is preserved for different values of $R$. Table 4 Regressions coefficient estimations confirm the significance of our hypothesis, but should be taken into account the significant values of errors that will have an effect depending on the size of the confidence interval.

Table 4. Regressions coefficient estimations

\begin{tabular}{|c|c|c|c|c|}
\hline & Coefficient & Standard error & t- statistics & P-value \\
\hline \multicolumn{5}{|c|}{ Israel } \\
\hline Y-interception & -120.08 & 19.91 & -6.03 & $3.75412 \mathrm{E}-06$ \\
\hline GDP & 24.71 & 1.57 & 15.75 & $8.23367 \mathrm{E}-14$ \\
\hline \multicolumn{5}{|c|}{ Ukraine } \\
\hline Y-interception & 6.98 & 8.83 & 0.79 & 0.437400653 \\
\hline GDP & 33.80 & 3.12 & 10.82 & $2.83669 \mathrm{E}-10$ \\
\hline
\end{tabular}

Source: Made by the author based on self-calculus

Ensar Essilurth in his studies determined that most of the expenditures are done by states that should increase their influence in the region at different levels, and this may be due both to increased defense spending of neighbors and participation in armed conflicts [21]. Could be assumed that sustained strong correlation and relation are the result of proportional control of defense expenditures. However, their model confirms that, based on GDP data analysis, 
countries are guided by the financing of the Armed Forces not only in proportion to their own GDP and neighbors' GDP [22]. The example of Israel is quite eloquent because the persistent high defense costs provide security in the region, which has a positive effect on the economic situation. This is confirmed this by conducting a risk analysis.

The way out for Ukraine in terms of reducing the financial burden on the budget is to become a member of NATO. Sandler and Harley noted that most European countries are NATO members, which is why they can control the amount of investment in defense at a sufficient minimum by translating them into other parties as well as partners of the Alliance [23]. The findings of the study highlighted that in general terms, side effects that have an impact on defense spending are significant. This certainly concerns this for Ukraine in the first place, due to the difficult situation in Eastern Europe.

The size and proportion of defense spending only reflect the general place and attention to defense issues in the state. However, it does not serve as a measure of costeffectiveness and is not related to the size of the army. The military-economic analysis deals with the assessment of the effectiveness and volume of spent time. Only using such methods analysts have the opportunity to make profound and sound conclusions about their expediency [2].

The question is how to measure and limit defense costs in order not to be bound in percentage terms to GDP, but to conduct an analysis according to functional features and expenditure directions. Raise their effectiveness and limit them so that it enables the Ukrainian economy to feel the necessary military-political stability to attract the necessary investments and ensure sustainable growth.

Conclusion. In the course of the study, work was carried out to determine the riskiness of economies and their potential attractiveness for foreign investors, in comparison, Israel and Ukraine, the states participating in long-term military conflicts, were used. Given the results, it can be concluded that Israel's economy may be interesting in terms of investment, while Ukraine is much riskier. Despite the higher average yield, the total cumulative income over the estimated period is much higher for Israel, despite the difficult situation in the region and the limited resources of the state. Markets in the study are well compared, which is confirmed by their correlation with the comparable US GDP.

Many economists confirm that defense spending is often a financial tool in cases of recession and stagnation of the economy. This is done by stimulating demand and solving problems with system deficits. Post-war politics is a confirmation of this fact in many developed countries. But standard economic approaches do not apply to developing countries. In the situation of acute deficits of domestic reserves in foreign currency and the reduction of financial capital, the issue of effective demand goes into the background. Defense expenditures create high alternative costs. This results in an increase in the burden on the budget and influences inflation. On the other hand, in most developing countries, procurement of armaments and military equipment is carried out at the expense of imports, and these costs also increase the negative impact on already limited foreign exchange resources.

However, in the event of a complex military-political situation in the region, defense spending is of prime importance. This is primarily due to the need to ensure the security, territorial integrity and integrity of the state. But, as have already mentioned, effective and functionally thought-out defense spending can create the necessary stability, despite participating in armed conflicts of the state. All these concerns and has an impact on the economic analysis of the financing of the Armed Forces, as well as their share in national expenditures, their quality, and orientation, such as the defense budget. In the future, it would be necessary to analyze and deduce the relationship between military-political stability in the region, the conditionally measured force of military formations and the quality and volume of defense spending. This will allow the inclusion of new variables in the system of macroeconomic forecasting of Ukraine's economic development that will increase the accuracy of the forecast. This may make it possible to decide and take into account in the further research a high level of uncertainty, which affects the quality of the analysis 


\section{REFERENCES}

1. Semenikhin I.M., Medvedjev Ju.B. \& Vashhenko I.V. (2006). Finansove zabezpechennja zbrojnykh syl $v$ umovakh rynkovoji ekonomiky Ukrajiny. Kyiv: Dim Dmytra Buragho [in Ukrainian].

2. Vykulov S. F., Zhukov G. P., V. N. Tkachev \& Ushakov V. Ja. (2001). Voennoekonomycheskyj analyz. Moscow: Voenyzdat [in Russia].

3. Fedosov V.M. (1991). Ghosudarstvennye fynansy [Ghosudarstvennye fynansy]. Kyiv; Lybidj [in Russian].

4. Andresjuk B.P. (2002). Reformuvannja Zbrojnykh Syl na suchasnomu etapi. Kyiv: Universytetsjke vydavnyctvo "Puljsar" [in Ukrainian].

5. Cheberiako, O. V. (2017). Finansove zabezpechennia oborony Ukrainy yak osnova natsionalnoi bezpeky v umovakh zbroinoi ahresii RF. Scientific Letters of Academik Society of Michal Baludansky, 5(2), 49-58 [in Ukrainian].

6. Cheberyako, O. V. \& Varnalii, Z. S. (2017). Financial Prerequisites And Assessment Of Defense Under The Conditions Of Russian-Ukrainian Hybrid War. Scientific Bulletin Of Polissia, 1(4(12)), 143-149. doi:10.25140/2410-9576-2017-1-4(12)-143-149.

7. Hatice K. Ç. (2009). A Theoretical Glance at Military Expenditures, Economic ResearchEkonomska Istraživanja, 22(4), 118-127, doi: 10.1080/1331677X.2009.11517395.

8. MSCI Global investible indexes market methodology (2019). Morgan Stanley Capital International. Retrieved from: https://www.msci.com/market-cap-weighted-indexes.

9. Sharpe, W. F., Alexander, G. J., \& Bailey, J. V. (2005). Investments, sixth edition. New Jersey: Prentice-Hall.

10. Pakholchuk V.V. (2019). Theoretical and Practical Approach to the Analysis of Financing Data of the Armed Forces of Ukraine and the Other Military Formations. Modern Economics, 13(1), 201-206. doi: 10.31521/modecon.V13(2019)-31.

11. Gross Domestic Product for Ukraine (2017) Federal Reserve Bank of St. Louis economic data. Retrieved from: https://fred.stlouisfed.org/series/MKTGDPUAA646NWDB\#0.

12. Gross Domestic Product for Ukraine (2017). World Bank economic data. Retrieved from: https://data.worldbank.org/country/ukraine.

13. Gross Domestic Product for the USA (2017). Federal Reserve Bank of St. Louis economic data. Retrieved from: https://fred.stlouisfed.org/series/GDPA.

14. Gross Domestic Product for Israel (2017). Federal Reserve Bank of St. Louis economic data. Retrieved from: https://fred.stlouisfed.org/series/MKTGDPILA646NWDB.

15. GDP Weighting in Asset Allocation (2015). Morgan Stanley Capital International. Retrieved from: https://www.msci.com/documents/10199/bd587385-8f67-423d-bd82-8e5ce52fa13b

16. OECD Economic Surveys (2018). Organisation for Economic Co-operation and Development. Retrieved from: https://www.oecd.org/eco/surveys

17. Razin, A. (2018). Israel and the world economy: The power of globalization. Cambridge, Mass.; London, England: The MIT Press.

18. Avigur-Eshel, A., \& Filc, D. (2017). Military Conflict and Neo-Liberalization in Israel (2001-2006): A Neo-Gramscian Approach. Political Studies, 66(2), 503-520. doi:10.1177/0032321717722356

19. SIPRI Military Expenditure Database (2018). Stockholm International Peace Research Institute. Retrieved from: https://www.sipri.org/databases/milex.

20. WMEAT World Military Expenditures and Arms Trade (2018). US Department of State. Retrieved from: http://www.state.gov/t/avc/rls/rpt/wmeat/.

21. Yesilyurt, M. E., \& Elhorst, J. P. (2017). Impacts of neighboring countries on military expenditures. Journal of Peace Research, 54(6), 777-790. doi:10.1177/0022343317707569

22. Phillips, B. J. (2014). Civil war, spillover and neighbors' military spending. Conflict Management and Peace Science,32(4), 425-442. doi:10.1177/0738894214530853

23. Sandler, T., \& Hartley, K. (2001). Economics of Alliances: The Lessons for Collective Action. Journal of Economic Literature, 39(3), 869-896. doi:10.1257/jel.39.3.869 